\title{
PPAR Ligands Induce Antiviral Effects Targeting Perturbed Lipid Metabolism during SARS-CoV-2, HCV, and HCMV Infection
}

\author{
Marialuigia Fantacuzzi (D), Rosa Amoroso (D) and Alessandra Ammazzalorso * (D)
}

Citation: Fantacuzzi, M.; Amoroso, R.; Ammazzalorso, A. PPAR Ligands Induce Antiviral Effects Targeting Perturbed Lipid Metabolism during SARS-CoV-2, $\mathrm{HCV}$, and HCMV Infection. Biology 2022, 11, 114. https://doi.org/ 10.3390/biology11010114

Academic Editor: Ligen Yu

Received: 7 December 2021

Accepted: 10 January 2022

Published: 11 January 2022

Publisher's Note: MDPI stays neutral with regard to jurisdictional claims in published maps and institutional affiliations.

Copyright: (C) 2022 by the authors. Licensee MDPI, Basel, Switzerland. This article is an open access article distributed under the terms and conditions of the Creative Commons Attribution (CC BY) license (https:// creativecommons.org/licenses/by/ $4.0 /$ )
Medicinal Chemistry Unit, Department of Pharmacy, G. d'Annunzio University of Chieti-Pescara, Via dei Vestini, 66100 Chieti, Italy; marialuigia.fantacuzzi@unich.it (M.F.); rosa.amoroso@unich.it (R.A.)

* Correspondence: alessandra.ammazzalorso@unich.it; Tel.: +39-0871-3554682

Simple Summary: The current coronavirus disease 2019 pandemic turned the attention of researchers to developing novel strategies to counteract virus infections. Despite several antiviral drugs being commercially available, there is an urgent need to identify novel molecules efficacious against viral infections that act through different mechanisms of action. In this context, our attention is focused on novel compounds acting on nuclear receptors, whose activity could be beneficial in viral infections, including coronavirus, hepatitis $C$ virus, and cytomegalovirus.

Abstract: The manipulation of host metabolisms by viral infections has been demonstrated by several studies, with a marked influence on the synthesis and utilization of glucose, nucleotides, fatty acids, and amino acids. The ability of virus to perturb the metabolic status of the infected organism is directly linked to the outcome of the viral infection. A great deal of research in recent years has been focusing on these metabolic aspects, pointing at modifications induced by virus, and suggesting novel strategies to counteract the perturbed host metabolism. In this review, our attention is turned on PPARs, nuclear receptors controlling multiple metabolic actions, and on the effects played by PPAR ligands during viral infections. The role of PPAR agonists and antagonists during SARS-CoV-2, $\mathrm{HCV}$, and HCMV infections will be analyzed.

Keywords: PPAR; viral infection; antiviral drug; lipid metabolism; SARS-CoV-2; HCV; HCMV

\section{Introduction: Targeting Metabolism during Viral Infections}

The viral reproduction needs the host cell machinery for the synthesis of viral components, such as nucleic acids and proteins. Clathrin-mediated endocytosis or micropinocytosis are the mechanisms allowing the internalization of viruses in the host, which are subsequently released in the cytosol. At this stage, the viral genome is released and transported into sites where the viral replication occurs [1]. After the replication of viral genome and the subsequent assembly of novel particles (virions), virus leaves from the host cell by exocytosis or lysis [2]. The metabolic capacity of the host cell is of primary importance to ensure the formation of novel virus particles, by supplying the necessary metabolites as amino acids, fatty acids, and nucleotides. Many viruses can manipulate the host metabolism to optimize their biosynthetic needs. The multiple effects played by viruses, involving glucose, lipid, and glutamine metabolism, were extensively reviewed by Eisenreich et al. [3]. The understanding of the nature of metabolic changes imposed by a viral infection is of paramount importance to identify a targeted therapy and obtain a successful outcome. For example, during the human immunodeficiency virus (HIV) infection, the inhibition of glucose metabolism determines the viral elimination, while during the late stages of HIV infection, the intervention on lipid metabolism has been proposed as a fruitful antiretroviral strategy [4,5]. Interestingly, the nutrition status plays a key role in influencing the outcome of viral infections: it is well known that malnutrition, especially a marked reduction in 
calorie intake, increases the susceptibility of children to viral diseases. Several studies have been conducted in animals to analyze the effects of diet supplementation, mainly vitamins, fat, fibers, and amino acids, during viral infections [6-9]. Several metabolic strategies have been proposed to target the viral replication in cell cultures and in vivo models. Figure 1 summarizes the main metabolic approaches pursued to manipulate virus metabolism, affecting the glucose, lipid, and glutamine metabolic pathways.

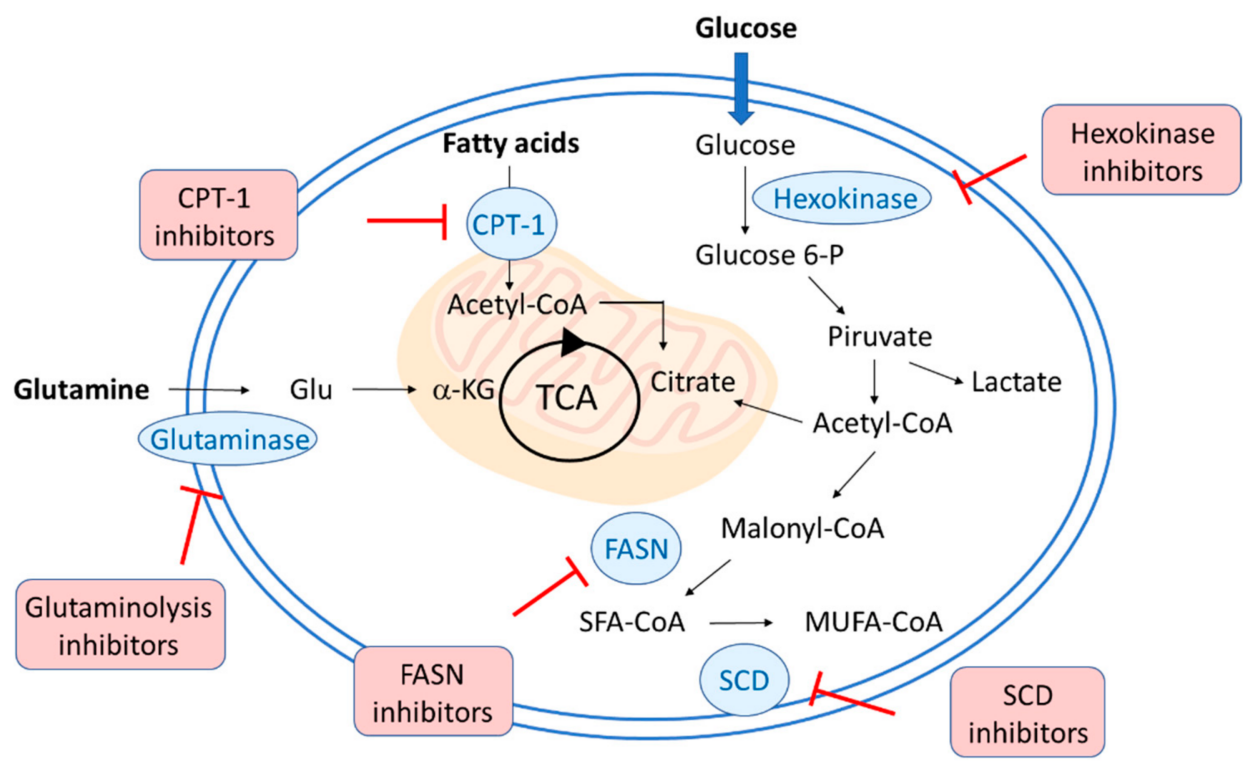

Figure 1. Schematic representation of the metabolic strategies to target viral replication. Hexokinase inhibitors interfere with glycolysis and glucose metabolism, whereas glutaminolysis inhibitors block the glutamate formation from glutamine. The lipid metabolism can be affected with different strategies: carnitine palmitoyl transferase 1 (CPT1) inhibitors block the entry of long-chain fatty acids into mitochondria for oxidation, fatty acid synthase (FASN or FAS) and stearoyl-CoA desaturase (SCD) inhibitors strongly interfere with lipogenesis.

Among several metabolic compounds tested for their antiviral activity, promising results were obtained with 2-deoxy-D-glucose (2-DG), which targets glucose metabolism, C75 and MK8245, which interferes with fatty acid metabolism, and CB-839, with its action on glutamine metabolism (Figure 2).

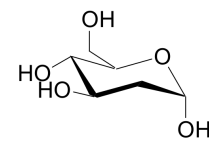

2-DG

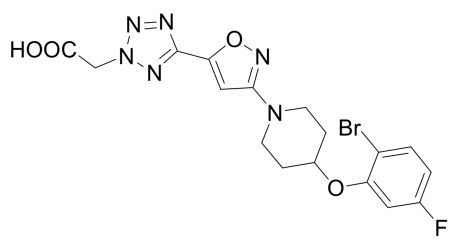

MK8245

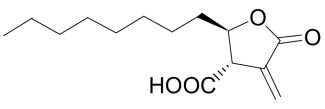

C75

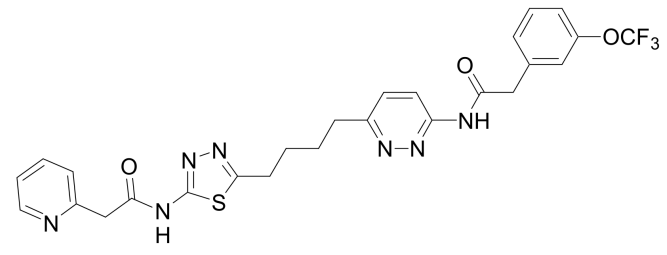

CB-839

Figure 2. Chemical structures of selected metabolic drugs tested to contrast the virus replication: 2-deoxy-D-glucose (2-DG, phosphoglucose isomerase inhibitor), C75 (FAS inhibitor), MK8245 (SCD1 inhibitor), and CB-839 (glutaminase inhibitor). 
2-DG is a synthetic glucose analog in which the 2-hydroxyl group is replaced by hydrogen. It undergoes an in vivo phosphorylation to 2-deoxy-D-glucose-6-phosphate, which remains trapped into cells, being unable to form its isomer fructose-6-phosphate. The intracellular accumulation of 2-deoxy-D-glucose-6-phosphate leads to the inhibition of glycolysis and glucose metabolism. 2-DG has been attracting interest also as a potential anticancer molecule, thanks to its non-toxic profile and its oral bioavailability [10-12]. The influence of 2-DG was studied in different viral infections, such as herpes simplex virus (HSV) [13], influenza virus [14], cytomegalovirus [15], rhinovirus [16]; very recently it has been proposed as an adjuvant therapeutic agent for COVID-19 treatment due to its effects on glycolysis, anti-inflammatory action, and interaction with viral proteins [17].

The possibility to interfere with fatty acid metabolism received great attention, considering it as an attractive target to regulate various and complex diseases as obesity, diabetes, cancer, and cardiovascular complications $[18,19]$. FAS (or FASN), a lipogenic enzyme catalyzing the condensation of acetyl-CoA and malonyl-CoA to produce long-chain fatty acids, has been proposed as a potential therapeutic target for an antiviral therapy. C75 is a synthetic FAS inhibitor, explored in many studies for its antitumor [20,21] and anti-obesity activities $[22,23]$. While fatty acid upregulation promotes the synthesis of lipid droplets, the inhibition of the fatty acid biosynthesis provides a mechanism by which the replication of several viruses can be decreased. This has been demonstrated for rotavirus replication, as reported by Gaunt et al. [24].

HIV-1 infection increases the intracellular levels of FAS, making this enzyme a novel host dependency factor with the potential to be exploited as an antiretroviral target [5]. In a similar way, it has been demonstrated that FAS inhibition impairs the replication of respiratory syncytial virus and other respiratory viruses [25].

FAS is upregulated during hepatitis $\mathrm{C}$ virus (HCV) infection and regulates the virus entry and production, suggesting that this mechanism could be responsible for the alteration of host cellular lipid profile and causing diseases such as steatosis [26]. The role of FAS in Epstein-Barr virus (EBV) lytic and latent infection has also been explored, showing that FAS plays an important role for the EBV lytic replication [27]. A recent paper describes the effects of C75 in coxsackievirus B3-infected human cells, with a significant decrease in the virus replication [28].

Stearoyl-CoA desaturase (SCD), an endoplasmic reticulum enzyme that catalyzes the biosynthesis of monounsaturated fatty acids (MUFAs) from saturated fatty acids, attracted a lot of attention for its regulation of multiple metabolic processes controlling cellular metabolism, cell cycle progression, survival, and differentiation. Several studies have demonstrated the involvement of SCD in the promotion of cancer cell proliferation, migration, metastasis, and tumor growth, suggesting this enzyme as a therapeutic target for the treatment of cancer $[29,30]$. While SCD has been shown to be a crucial factor in the lipid metabolism and body weight control, its inhibitors are claimed to be beneficial for the treatment of different diseases, such as skin disorders, nonalcoholic steatohepatitis (NASH), $\mathrm{HCV}$, Alzheimer's disease, or cancer [31].

There is an emerging body of evidence that the lipid pathways play an important role in HCV's formation of membranous replication complexes. Since it has been shown that inhibiting lipogenesis negatively affects HCV replication, SCD1 inhibition may also be a novel therapeutic strategy for the treatment of HCV infection $[32,33]$. The SCD inhibitor MK8245 has been evaluated as an option for anti-HCV multidrug therapy, showing a low risk of emergence of drug-resistant HCV and any significant side effects [34]. Analogously, this compound has been studied against Dengue virus (DENV) infection; it dramatically induced a dose-dependent suppression of DENV replication, without producing cytotoxicity. Interestingly, its efficacy was observed against four DENV serotypes and other flaviviruses, including Zika virus and Japanese encephalitis virus [35].

The glutamine metabolism represents another accessible step for inhibition to obtain a reduction in viral infections. Among the different proposed strategies, targeting glutaminolysis via glutaminase inhibition emerged as a promising strategy to interfere with 
metabolism. The first step of glutaminolysis, the conversion of glutamine to glutamate, can be reduced by glutaminase inhibitors, which also determine the rise of intracellular ROS levels, and the impairment of GSH production. Due to the critical role of glutaminolysis in cancer metabolism, glutaminase has been proposed as a viable target for cancer therapy [36]. Among several glutaminase inhibitors identified, allosteric inhibitors, such as CB-839 (telaglenastat), appear advantageous, as they selectively target glutaminase without affecting other aspects of glutamine metabolism. CB-839 displayed significant antitumor activity in triple negative breast cancer models [37], head and neck cancer squamous cell carcinoma (HNSCC) [38], hematological malignancies [39,40], and it is currently under clinical trials in solid tumors and in advanced myelodysplastic syndrome. The possibility to use CB-839 in viral infections has been recently explored; CB-839 treatment reduced the viral replication of adenovirus, HSV-1, and influenza A in cultured primary cells [41].

\section{Changes in Lipid Metabolism during SARS-CoV2, HCV, and HCMV Infection}

Lipid metabolism plays a crucial role during the different stages of viral infection, representing an adaptive metabolic response of host organisms. Modifications of lipid metabolism are related to fatty acid metabolism, biosynthesis of sterols and phosphoinositides, and utilization of lipid stores. Many viruses induce high glucose metabolism (Warburg effect) and change the lipid metabolism from fatty acid oxidation (FAO) to fatty acid synthesis. The increase in FAS is mainly necessary for enveloped viruses such as COVID-19, influenza, hepatitis B and C and others [42,43]. Metabolic changes induced by virus infection provide potential target to contrast the infection. The outcome of viral infections is strongly related to the metabolic conditions of host, including obesity, diabetes mellitus, metabolic syndrome, and endocrine diseases. In addition, the state of nutrition has been shown an important factor in determining the evolution of viral infections, by altering multiple metabolic pathways.

$\mathrm{HCV}$ infection, the main cause of hepatitis, cirrhosis, and hepatocellular carcinoma, exerts a strong influence on host lipid metabolism [44]. Consequently, hypolipidemia and hepatic steatosis are conditions frequently occurring in chronic hepatitis $\mathrm{C}$ patients. These metabolic changes in host highlight the close interplay between HCV and the lipid metabolism, with lipids and lipoproteins playing a crucial role in the virus lifecycle [45]. A strict relationship between lipids and $\mathrm{HCV}$ is necessary for the mechanism of viral entry into hepatocytes, replication, particles assembly and secretion [46]. While lipids and their receptors are key players in the early stages of HCV infection, molecules targeting lipids or their receptors could be considered as novel strategies against HCV infection, by preventing or limiting virus-induced damages [47]. Likewise, HCV, hepatitis B virus (HBV), is considered a metabolic virus, as it affects many hepatic metabolic pathways [48]. Several studies based on cell lines and mouse models explored the mechanisms by which HBV infection affects lipid metabolism but, to date, results are not conclusive. HBV virus induces extensive changes in hepatic lipid metabolism, by activating the expression of some proteins or upregulating fatty acid oxidation. For example, the HBV infection induces sterol regulatory element-binding protein 1c (SREBP1c) activation, with upregulation of lipogenic enzymes, such as FAS, SCD, acetyl-CoA carboxylase (ACC), and thus fatty acid synthesis [49].

Several studies on members of the Coronaviridae family demonstrated the importance of lipids in different steps of the virus lifecycle, although the exact mechanisms need to be fully elucidated [50]. The early stage of coronavirus infection includes events prior to the viral RNA replication and involves the virus fusion with host membrane and endocytosis, whereas the late stage involves the RNA replication, the synthesis of proteins, the viral particle assembly and release. Following the early interaction with membrane lipids, such as cholesterol, the internalized virus leads to an extensive reorganization of host lipid profile, necessary to the genome replication of virus. It is not surprising that a specific lipid profile, perturbed by the virus action, is requested to ensure a productive infection. 
Human cytomegalovirus (HCMV) is a common herpesvirus that causes lifelong persistent infections. While infection is asymptomatic in most people, HCMV induces lifethreatening illnesses in immunocompromised people, mainly in transplant recipients and cancer patients. In addition, HCMV infection is a leading cause of congenital disabilities. HCMV replication is strongly related to host metabolism; in fact, the CMV infection alters the activity in multiple metabolic pathways, including fatty acid elongation and lipid synthesis. The regulation of multiple factors in the host organism, such as kinases and transcription factors, are important for metabolic changes occurring after HCMV infection. A comparative study was carried out to assess the influence of two enveloped viruses, HCMV and HSV-1, on host metabolism [51]. It is interesting to observe that both viruses do not rely passively on host metabolic activity, but they actively redirect metabolism, by following different metabolic programs. HCMV determines an increased lipid metabolism, raising the glycolytic flux, FAS, lactate excretion, and increasing the levels of many molecules involved in TCA cycle. Differently from HCMV, HSV-1 shows less reliance on FAS, while its envelope is mainly formed from preexisting cellular material, whereas it upregulates flux from glucose to de novo pyrimidine nucleotide biosynthesis. These divergent metabolic strategies represent an important point to interfere with metabolic changes induced by viruses, allowing us to point out different metabolic processes to obtain novel antiviral strategies.

A recent study indagated on viral factors required to alter metabolism, by identifying the HCMV UL37x1 protein (pUL37x1) as a key factor for infection-associated increases in lipid metabolism [52]. This protein was found to be crucial for the increased lipid metabolism, being involved in fatty acid elongation to synthesize very long chain fatty acids (VLCFAs). The HCMV infection resulted also in a sensible increase in phospholipids, mainly those possessing VLCFA tails. Through a combined metabolomic and lipidomic approach, this study demonstrated the impact of the viral UL37x 1 protein in remodeling host lipid metabolism.

\section{PPARs in Viral Infections}

Peroxisome Proliferator-Activated Receptors (PPARs), belonging to the nuclear receptor superfamily, are transcription factors playing well-established roles in several metabolic pathways in the organism, including lipid and glucose metabolism, energetic homeostasis, cell differentiation and proliferation. Since their discovery, a body of knowledge has been collected on them, and the three receptor subtypes (PPAR $\alpha, \operatorname{PPAR} \gamma, \operatorname{PPAR} \beta / \delta$ ) have attracted a great deal of efforts by medicinal chemists to identify novel drugs targeting the metabolism. PPAR agonists, antagonists, and modulators represent important pharmacological tools to induce beneficial therapeutic effects in metabolic disorders, such as metabolic syndrome, obesity, diabetes, and others [53-56]. Recently, PPARs have been attracting a great deal of interest as targets in different cancers, thanks to their ability to induce important metabolic changes in tumors, and several PPAR ligands have been studied for their possible antitumor effects [57-60].

The involvement of PPARs in viral infections is quite a recent matter of investigation, and the interest in this field received a strong impulse due to the pandemic by COVID-19. PPAR agonists, antagonists, or modulators could induce different effects in models of infections; in the following sections, the main results obtained from in vitro and in vivo studies will be analyzed and discussed. In addition, PPAR modulators may act as agonist or antagonist depending on the cellular context, based on the variable presence of coactivators or corepressors in specific tissues. Unfortunately, it is currently impossible to precisely categorize the effects of PPAR ligands in viral infections, so as identify the exact mechanism of action responsible for the observed antiviral outcome. In next paragraphs main evidence on PPAR involvement in the most studied infections (SARS-CoV-2, HCV, and HCMV) will be analyzed, focusing on the description of PPAR ligands and the beneficial effects observed in models of infection. 


\subsection{Antiviral Effects Played by PPAR Ligands in SARS-CoV-2 Infection}

The COVID-19 pandemic is an ongoing global problem caused by severe acute respiratory syndrome coronavirus 2 (SARS-CoV-2). A very large body of studies has been conducted on this subject, with a recent investigation demonstrating that cell lipid profile is significantly altered during the infection by human coronavirus [61]. COVID-19 progression has been suggested to have a metabolic origin, while elevated glucose and lipid levels are risk factors. The SARS-CoV-2 spike protein mediates the viral cellular entry via the ACE2 receptor. Recent findings have revealed that ACE2 is downregulated in SARS-CoV-2-infected lung tissue [62]. The stimulation of ACE2 could play a protective role in the treatment of hypertension, heart disease, cancer, and COVID-19 [63], while these disorders show the upregulation of the WNT/ $\beta$-catenin pathway. For these reasons, pharmacological agents increasing the ACE2 expression, such as statins and PPAR $\gamma$ agonists, could be beneficial in the treatment of COVID-19.

In Figure 3 are summarized the chemical structures of natural and synthetic PPAR ligands explored in in vitro assays or proposed as possible antiviral agents against SARS-CoV-2 infection.

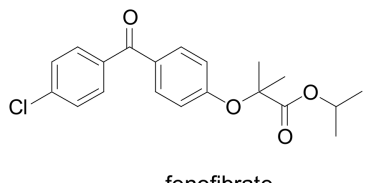

fenofibrate
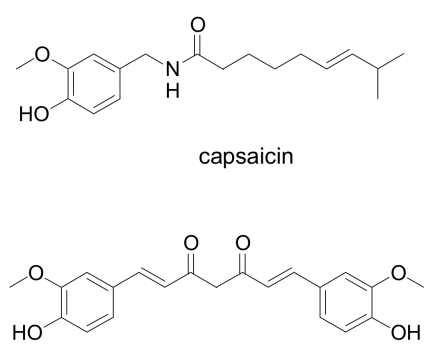

curcumin

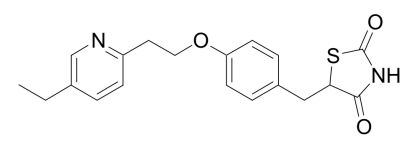

pioglitazone

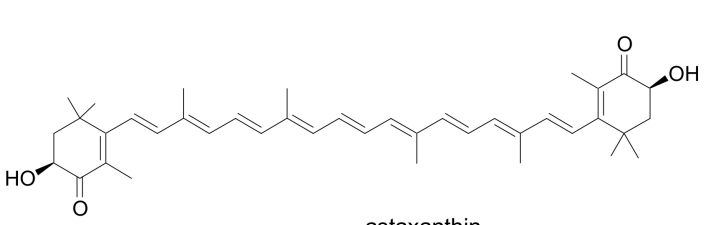

astaxanthin

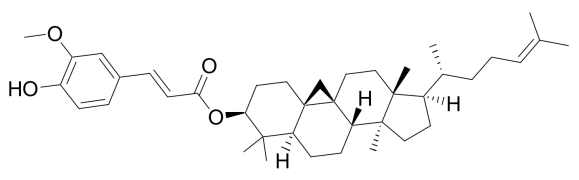

gamma oryzanol

Figure 3. Chemical structures of natural and synthetic PPAR ligands explored in in vitro assays or proposed as possible antiviral agents against SARS-CoV-2 infection.

Emerging studies suggest that SARS-CoV-2 alters lipid metabolism in the lung epithelial cells by modulating PPAR $\alpha$, possibly contributing to lipotoxicity and respiratory effects. The reduced PPAR $\alpha$ activity could be responsible for the pulmonary inflammation, playing an important role in the pathogenesis of acute lung injury. For these reasons, the use of PPAR $\alpha$ agonists may be a useful therapeutic strategy to reverse the inflammatory and metabolic changes induced by SARS-CoV-2 [64]. A recent study showed that the PPAR $\alpha$ agonist fenofibrate reversed the metabolic changes caused by SARS-CoV- 2 and inhibited the viral replication in lung epithelial cells [65]. Fenofibrate was found to inhibit the cytopathic effect exerted by SARS-CoV-2 on Vero E6 cells at $20 \mu \mathrm{M}$ [66]. The PPAR $\alpha$ agonist palmitoylethanolamide (PEA) has well-known anti-inflammatory effects, and a very recent study identified the putative mechanisms by which this compound could represent a promising adjuvant in the current COVID-19 therapeutic protocols [67]. By the selective activation of PPAR $\alpha$, in primary cultures of murine alveolar macrophages PEA antagonizes the nuclear factor $\mathrm{kB}(\mathrm{NF}-\mathrm{kB})$ signalling pathway, decreasing the production of tumor necrosis factor alpha (TNF- $\alpha$ ), interleukin $\beta$ (IL-1 $\beta$ ) and other inflammatory mediators.

$\operatorname{PPAR} \gamma$ has been appointed as a promising target for the treatment of viral influenza associated with the inflammatory pathways occurring during the cytokine storm. By targeting 
inflammation, ACE2 and the WNT / $\beta$-catenin pathway, PPAR $\gamma$ agonists may be interesting candidates for delivering SARS-CoV-2 therapy in clinical settings [68]. The stimulation of PPAR $\gamma$ by natural or synthetic agonists could exert a regulatory role on the cytokine storm typical of virus infections, by preventing the cytokine overproduction and the inflammatory cascade. Natural PPAR $\gamma$ ligands, including curcumin, capsaicin, docosahexaenoic acid, eicosapentaenoic acid, have been proposed for possible use in COVID-19 [69].

The use of PPAR $\gamma$ agonist pioglitazone was recently analyzed in people affected by type 2 diabetes for the risk of increased morbidity and mortality in COVID-19 infection [70]. By considering the literature data, pioglitazone has more potential for benefit than harm, and can be continued in diabetic people with mild/moderate COVID-19. In addition, pioglitazone has been indicated as a potential 3-chymotrypsin-like protease (3CL-Pro) inhibitor, which could downregulate SARS-CoV-2 RNA synthesis and replication [71]. This interesting concept needs further investigation to assess the real role of pioglitazone during SARS-CoV-2 infection. Pioglitazone has been also proposed as an effective treatment in COVID-19 patients with diabetes, hypertension, and cardiovascular comorbidities, thanks to its ability to reduce inflammatory parameters [72].

Natural compounds have also been investigated as possible coadjuvant therapy to prevent the cytokine storm in COVID-19 patients with obesity conditions. Gamma-oryzanol, the main bioactive constituent from rice bran and germ, has been found to positively modulate PPAR $\gamma$ expression in adipose tissue, reducing the levels of TNF- $\alpha$, interleukin-6 (IL-6) and monocyte chemoattractant protein-1 (MCP-1) [73].

For its potent and multiple PPAR activity, astaxanthin was studied as an effective therapeutic strategy to regulate the host inflammatory and immune responses, contrast the cytokine storm, and prevent the inflammatory effects following COVID-19 [74]. Several in vitro and in vivo studies related to astaxanthin showed beneficial effects in alleviating the risk of inflammatory cytokine, thereby supporting its likely therapeutic benefits against cytokine storm in COVID-19 infection. However, to date, the antiviral action of astaxanthin requires further investigation.

Interestingly, a recent study proposes PPAR $\alpha$ and PPAR $\gamma$ agonists as adjuvants for COVID-19 vaccine, thanks to their ability to enhance both $B$ and T memory cells through different mechanisms [75].

To the best of our knowledge no studies have been reported to date concerning the involvement of PPAR $\delta$ on COVID-19 infection and the possible beneficial effects induced by PPAR $\delta$ selective agonists or antagonists. Overall, results from literature studies suggest the lipid metabolism regulation through PPAR $\alpha$ and PPAR $\gamma$ would be a druggable target against coronavirus infections. In Table 1 results from published studies are summarized, pointing at PPAR ligands, concentration, infected cell models, and observed outcome in SARS-CoV-2 infection. In addition, PPAR ligands proposed as anti-SARS-CoV-2 agents are reported, based on their anti-inflammatory, antioxidant, and immunomodulating properties.

Despite the evidence arising from the studies reviewed, a clear understanding on the real suitability of the clinic use of PPAR drugs during COVID-19 infection is so far yet to be elucidated. PPAR ligands, such as glitazones, can also induce biological effects through a PPAR $\gamma$-independent mechanism, as widely demonstrated for cytotoxic effects in different in vitro cancer models [76]. The cytotoxicity induced by troglitazone in human renal cell carcinoma cell lines has been demonstrated to be independent by PPAR $\gamma$ pathway [77]; analogously, the antiproliferative effect induced by fenofibrate in human hepatoma cell line Huh7 was not related to PPAR $\alpha$ stimulation, while this effect was not suppressed by using the selective PPAR $\alpha$ antagonist GW6471 [78]. These findings support the high versatility of PPAR drugs in inducing pleiotropic effects, and this aspect is also complicated by the need to reach elevated concentrations of drug to observe the desired pharmacological effect [79]. 
Table 1. Summary of PPAR ligands in vitro tested in SARS-CoV-2 infection or proposed as anti-SARS-

CoV-2 agents.

\begin{tabular}{|c|c|c|c|c|c|}
\hline Cpd & PPAR Activity & Concentration & Cell & Outcome & Ref. \\
\hline Fenofibrate $\left(\right.$ Tricor $\left.^{\circledR}\right)$ & $\operatorname{PPAR} \alpha$ agonist & $20 \mu \mathrm{M}$ & $\begin{array}{l}\text { Human bronchial } \\
\text { epithelial cells }\end{array}$ & $\begin{array}{l}\text { Block viral replication, reverted effects on } \\
\text { phospholipid accumulation and glycolysis }\end{array}$ & {$[65]$} \\
\hline Fenofibrate & PPAR $\alpha$ agonist & $20 \mu \mathrm{M}$ & Vero E6 cells & Block viral entry & {$[66]$} \\
\hline Palmitoylethanolamide & PPAR $\alpha$ agonist & $10^{-9}-10^{-7} \mathrm{M}$ & $\begin{array}{l}\text { murine alveolar } \\
\text { macrophages }\end{array}$ & $\begin{array}{l}\text { Inhibition of NF- } \kappa \text { B transcription and } \\
\text { NLRP-3 inflammasome signaling, with a } \\
\text { significant antinflammatory effect }\end{array}$ & [67] \\
\hline Pioglitazone & PPAR $\gamma$ agonist & - & - & $\begin{array}{l}\text { Proposed as 3CL-Pro inhibitor, it could } \\
\text { downregulate SARS-CoV-2 RNA synthesis } \\
\text { and replication } \\
\text { Proposed as an additive in COVID-19 } \\
\text { patients with diabetes, hypertension, and } \\
\text { cardiovascular comorbidities for its } \\
\text { antinflammatory properties }\end{array}$ & {$[71,72]$} \\
\hline $\begin{array}{l}\text { Curcumin, capsaicin, } \\
\text { docosahexanoic acid, } \\
\text { eicosapentaenoic acid }\end{array}$ & $\begin{array}{l}\text { Natural PPAR } \gamma \\
\text { agonists }\end{array}$ & - & - & $\begin{array}{c}\text { Proposed for use in COVID-19, } \\
\text { due to their ability to prevent cytokine } \\
\text { overproduction and inflammatory cascade }\end{array}$ & [69] \\
\hline Gamma-oryzanol & PPAR $\gamma$ modulator & - & - & $\begin{array}{l}\text { Proposed for use in COVID-19, } \\
\text { due to its anti- inflammatory and } \\
\text { antioxidant properties }\end{array}$ & [73] \\
\hline Astaxanthin & $\begin{array}{l}\text { Multiple action on } \\
\text { PPARs: PPAR } \alpha \\
\text { agonist, PPAR } \delta \\
\text { antagonist, PPAR } \gamma \\
\text { agonist or antagonist }\end{array}$ & - & - & $\begin{array}{l}\text { Proposed for use in COVID-19, } \\
\text { due to the ability to reduce the } \\
\text { oxidative stress induced by ROS, the } \\
\text { immune response, and the production of } \\
\text { pro-inflammatory cytokines }\end{array}$ & [74] \\
\hline
\end{tabular}

\subsection{Antiviral Effects Played by PPAR Ligands in HCV Infection}

The role of PPARs in controlling glucose and lipid metabolism in hepatocytes is well established, leading to liver inflammation and fat accumulation, which represent hallmarks of chronic HCV infection. To date, many studies have been carried out to clarify the exact correlation between PPARs and HCV infection [80]. PPARs are highly expressed in hepatocytes in normal conditions, whereas it has been demonstrated an altered liver PPAR $\alpha$ and $\gamma$ expression during HCV infection [81-83]. The correlation between PPAR $\alpha$ expression and $\mathrm{HCV}$ attracted a great deal of attention, this isoform being a major player in the liver lipid homeostasis.

In Figure 4, chemical structures of natural and synthetic PPAR ligands tested in in vitro or in vivo studies against HCV infection are displayed.

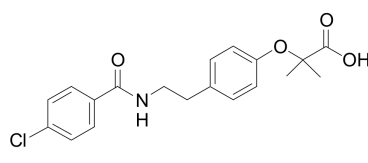

bezafibrate

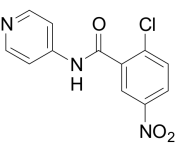

T0070907

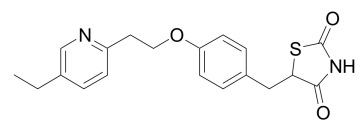

pioglitazone

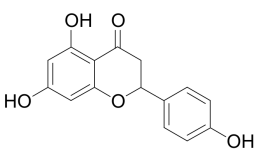

naringenin

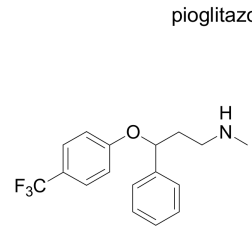

fluoxetine

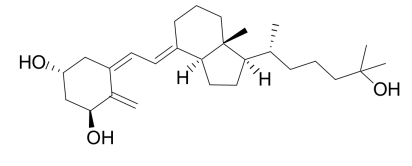

calcitriol

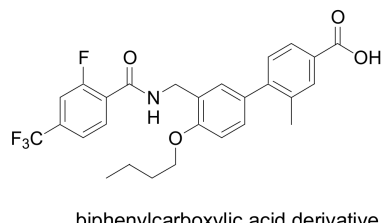

Figure 4. Chemical structures of natural and synthetic PPAR ligands displaying in vivo or in vitro efficacy in HCV infection models. 
The effects of bezafibrate, a classical PPAR pan agonist, were indagated in pilot studies of chronic HCV infection [84-86]. At the endpoint, the viral load and liver enzymes were significantly decreased, suggesting antiviral and anti-inflammatory properties of bezafibrate. An oral treatment with bezafibrate $(400 \mathrm{mg}$ /day for 8 weeks) was effective in patients with chronic hepatitis C, by reducing serum HCV RNA. The evidence of an association between HCV and LDL levels in serum suggests the potential usefulness of bezafibrate as an anti-HCV agent.

The PPAR $\gamma$ agonist pioglitazone was found to induce a similar effect, by producing a decrease in the HCV viral load [87]. A pilot study was conducted on overweight genotype $4 \mathrm{HCV}$-infected patients from Egypt; the treatment with pioglitazone at $30 \mathrm{mg} /$ day for 14 days of treatment was effective in decreasing serum HCV RNA at day-14. Pioglitazone treatment decreased also fasting serum glucose, and induced modifications on liver injury indicators, as serum alanine aminotransferase and, to a smaller degree, aspartate aminotransferase levels.

The grapefruit flavonoid naringenin dose-dependently inhibited HCV production blocking the assembly of viral particles [88]. This antiviral effect was in part ascribed to $\operatorname{PPAR} \alpha$ activation, leading to a decreased VLDL production without causing hepatic lipid accumulation in Huh7.5.1 cells and primary human hepatocytes. Additionally, long-term treatment with naringenin $(200 \mu \mathrm{M}$ for 4 days of treatment) led to a rapid inhibition of $\mathrm{HCV}$ production.

An interesting study showed that the antidepressant drug fluoxetine exerts antiviral effects in an HCV model [89]. Fluoxetine could represent a novel treatment for HCV infection through reduction in ROS generation, reduced lipid accumulation and activation of c-Jun amino-terminal kinases (JNK) and PPAR $\gamma / \delta$ pathways. PPAR $\gamma$ and PPAR $\delta$ antagonists reverted the inhibitory effect on $\mathrm{HCV}$ infection and lipid accumulation, confirming the involvement of these nuclear receptors in the mechanism of antiviral activity; conversely, PPAR $\alpha$ antagonist GW6471 showed no effect.

Interestingly, a recent study shows that the antiviral effects played by calcitriol are associated with a reduced PPAR activation [90]. HCV-infected Huh7.5 human hepatoma cells (MOI 0.01) were treated with various concentrations of calcitriol for 6 days of treatment. By blocking three PPAR isotype activation, calcitriol produced the partial inhibition of HCV infection via PPAR $\alpha / \gamma$, the relief of nitrative stress via PPAR $\beta / \gamma$ and the reduction in lipid accumulation via PPAR $\gamma$. These effects were reverted in the presence of PPAR agonists Wy14643, Ly171883, and linoleic acid.

The PPAR $\alpha / \gamma$ antagonist 2-chloro-5-nitro- $N$-(pyridyl)benzamide (T0070907) displayed a significant anti HCV effect in Huh-7 cells, related to the ability of this molecule to suppress the PPAR $\alpha$ activity [91]. The decrease in viral replication in in vitro studies $\left(\mathrm{IC}_{50}\right.$ $19.1 \mu \mathrm{M}$ ) was linked to the misregulation of lipid homeostasis, leading to increased lipid content. However, the exact mechanism by which PPAR $\alpha$ inhibits HCV lifecycle needs to be fully clarified.

The possible antiviral effects played by PPAR $\delta$ antagonists were also investigated [92]. A group of biphenyl carboxylic acids with PPAR $\delta$ antagonist properties were found to dosedependently inhibit HCV RNA replication, indicating that PPAR $\delta$ pathway is also involved in antiviral effects. The best compound of this series displayed a submicromolar potency $\left(\mathrm{EC}_{50} 0.22 \mu \mathrm{M}\right)$ and a weak cytotoxicity against host cells. Interestingly, the combinations of this compound with pegylated interferon alpha (Peg-IFN $\alpha$ ) or Peg-IFN $\alpha$ and ribavirin were also able to improve the outcome of HCV infection, leading to a synergistic decreased HCV RNA replication.

A summary of PPAR ligands tested in in vivo or in vitro HCV infection models is depicted in Table 2. 
Table 2. Summary of PPAR ligands in vivo or in vitro tested in HCV infection.

\begin{tabular}{|c|c|c|c|c|c|}
\hline Cpd & PPAR Activity & Concentration & Model & Outcome & Ref. \\
\hline Bezafibrate & PPAR pan agonist & $\begin{array}{l}400 \mathrm{mg} / \text { day for } \\
8 \text { weeks }\end{array}$ & $\begin{array}{l}\text { Chronic hepatitis } C \text { patients } \\
\text { complicated with } \\
\text { hyperlipidemia }\end{array}$ & Decreased serum HCV RNA & [86] \\
\hline Pioglitazone & PPAR $\gamma$ agonist & $\begin{array}{l}30 \mathrm{mg} / \text { day for } \\
14 \text { days }\end{array}$ & $\begin{array}{l}\text { Overweight Genotype } 4 \\
\text { HCV patients }\end{array}$ & Decreased serum HCV RNA at day 14 & [87] \\
\hline Naringenin & PPAR $\alpha$ agonist & $200 \mu \mathrm{M}$ & HCV-infected Huh7.5.1 & $\begin{array}{l}\text { Inhibition of ApoB-100 and HCV } \\
\text { RNA secretion }\end{array}$ & [88] \\
\hline Fluoxetine & $\begin{array}{l}\text { PPAR } \gamma / \delta \\
\text { modulator }\end{array}$ & $\begin{array}{l}0.1-10 \mu \mathrm{M} \text { for } \\
6 \text { days }\end{array}$ & HCV-infected Huh7.5 cells & $\begin{array}{l}\text { Decrease in virus protein levels of core, } \\
\text { NS3, and NS5A. Reduction in ROS } \\
\text { generation and lipid accumulation }\end{array}$ & [89] \\
\hline Calcitriol & $\begin{array}{l}\operatorname{PPAR} \alpha / \gamma / \delta \\
\text { modulator }\end{array}$ & $0.1-1000 \mathrm{nM}$ & HCV-infected Huh7.5 cells & $\begin{array}{l}\text { Decrease in viral infection, nitrative } \\
\text { stress, and lipid accumulation }\end{array}$ & [90] \\
\hline T0070907 & $\begin{array}{l}\mathrm{PPAR} \alpha / \gamma \\
\text { antagonist }\end{array}$ & $\mathrm{IC}_{50} 19.1 \mu \mathrm{M}$ & $\begin{array}{l}\text { Huh-7 cells expressing an } \\
\text { HCV subgenomic replicon }\end{array}$ & Inhibition of HCV replication & [91] \\
\hline $\begin{array}{l}\text { Biphenyl } \\
\text { carboxylic } \\
\text { acids }\end{array}$ & PPAR $\delta$ antagonists & $\begin{array}{c}2.5-10.0 \mu \mathrm{M} \\
\text { most potent } \\
\text { compound } \mathrm{EC}_{50} \\
0.22 \mu \mathrm{M}\end{array}$ & OR6 HCV replication system & $\begin{array}{l}\text { Dose-dependent inhibition of HCV } \\
\text { RNA replication. Synergistic antiviral } \\
\text { effect when tested in combination with } \\
\text { Peg-IFN } \alpha \text { or Peg-IFN } \alpha \text { and ribavirin }\end{array}$ & [92] \\
\hline
\end{tabular}

\subsection{Antiviral Effects Played by PPAR Ligands in HCMV Infection}

Although infection by HCMV is usually benign, congenital infection is a leading cause of permanent abnormalities of the CNS. In addition, HCMV infection contributes to the development of pathological states in immune-compromised hosts such as AIDS patients and transplant recipients. The relationships between HCMV infection and PPARs have been explored, given the known role of PPARs, mainly PPAR $\gamma$ isotype, in lipogenesis and inflammation. Experiments provided evidence that PPAR $\gamma$ transcriptional activity is induced in HCMV-infected cells, as evidenced by nuclear translocation and lipid accumulation [93]. The PPAR $\gamma$ activation by HCMV is involved in defective trophoblastic migration and invasion processes, being PPAR $\gamma$ a major player in cytotrophoblast differentiation and function.

The effects of HCMV infection in human immortalized extravillous cytotrophoblasts (HIPEC) were also analyzed, identifying 15-hydroxyeicosatetraenoic acid (15-HETE) and 13-hydroxyoctadecadienoic acid (13-HODE) as predominant PPAR $\gamma$ agonists secreted after HCMV infection [94]. The PPAR $\gamma$ stimulation by these natural ligands results in impaired migration abilities and enhanced viral replication, confirming the important role of PPAR $\gamma$ in HCMV infection.

In addition, the role of PPAR $\gamma$ in neurogenesis during congenital HCMV infection was deeply studied in neural stem cells from human embryonic stem cells (NSCs) [95]. This study confirmed a key role for PPAR $\gamma$ in neurogenesis and in the pathophysiology of HCMV infection, displaying that viral infection triggers PPAR $\gamma$ levels in NSCs. Infected cells produce increased levels of 9-hydroxyoctadecadienoic acid (9-HODE), which is responsible for enhanced viral replication and impaired neurogenesis. The treatment of infected NSCs with the PPAR $\gamma$ antagonist T0070907 restored a normal rate of differentiation.

To date, only the relationship of HCMV-PPAR $\gamma$ has been reported in the literature, and details about the use of PPAR $\gamma$ agonists or antagonists are not available. To the best of our knowledge, no studies have been published focusing on the possible effects played by PPAR $\alpha$ and PPAR $\delta$ pathways during HCMV infection.

\section{Conclusions}

The strict interplay existing between virus and host metabolism offers the possibility to interfere with metabolic pathways as an attractive novel strategy to obtain a successful outcome in viral infections. The possibility to target PPARs has received attention in recent years, given the well-established roles of these nuclear receptors in glucose and lipid 
metabolism. However, to date, a limited number of experimental studies describing PPAR ligands tested in viral infections are available, and they mainly involve SARS-CoV-2, HCV, and HCMV infections. These studies were reviewed in this work, pointing at chemical structures, mechanisms of action on three PPAR isoforms (agonist, antagonist, modulator), and the outcomes observed in in vitro and in vivo models of infection. Unfortunately, it is currently impossible to precisely categorize the effects of PPAR ligands in viral infections, so as to identify the exact mechanism of action responsible for the observed antiviral effects. In SARS-CoV-2 infection, the use of PPAR ligands could induce beneficial effects by preventing the cytokine overproduction and the subsequent inflammatory cascade. Additionally, in HCV, the use of PPAR agonists and antagonists was found to be effective to decrease viral levels in patients or in in vitro cell models. Very little is known about the possibility to use a PPAR ligand to contrast the HCMV infection; however, some studies provide evidence about the relationships between PPARs and HCMV infection, suggesting PPAR ligands as therapeutic options in the management of HCMV-infected patients. A deeper understanding of viral interactions with host metabolism is necessary to provide novel therapeutic options in the fight against viral diseases. A further aspect to be clearly elucidated is to know the exact mechanism of action of PPAR drugs, excluding possible off targets effects.

Author Contributions: Conceptualization and supervision: A.A.; literature review: A.A., M.F. and R.A.; writing and review: A.A., M.F. and R.A. All authors have read and agreed to the published version of the manuscript.

Funding: This research received no external funding.

Institutional Review Board Statement: Not applicable.

Informed Consent Statement: Not applicable.

Data Availability Statement: Not applicable.

Conflicts of Interest: The authors declare no conflict of interest.

\section{Abbreviations}

$\begin{array}{ll}\text { 13-HODE } & \text { 13-Hydroxyoctadecadienoic acid } \\ \text { 15-HETE } & \text { 15-Hydroxyeicosatetraenoic acid } \\ \text { 2-DG } & \text { 2-Deoxy-D-glucose } \\ \text { 3CL-Pro } & \text { 3-Chymotrypsin-like protease } \\ \text { 9-HODE } & \text { 9-Hydroxyoctadecadienoic acid } \\ \text { ACC } & \text { Acetyl-CoA carboxylase } \\ \text { CPT1 } & \text { Carnitine palmitoyl transferase 1 } \\ \text { DENV } & \text { Dengue virus } \\ \text { EBV } & \text { Epstein-Barr virus } \\ \text { FAO } & \text { Fatty acid oxidation } \\ \text { FAS (or FASN) } & \text { Fatty acid synthase } \\ \text { GSH } & \text { Glutathione } \\ \text { HBV } & \text { Hepatitis B virus } \\ \text { HCMV } & \text { Human cytomegalovirus } \\ \text { HCV } & \text { Hepatitis C virus } \\ \text { HIPEC } & \text { Human immortalized extravillous cytotrophoblasts } \\ \text { HIV } & \text { Human immunodeficiency virus } \\ \text { HNSCC } & \text { Head and neck cancer squamous cell carcinoma } \\ \text { HSV } & \text { Herpes simplex virus } \\ \text { IL-1 } 3 & \text { Interleukin 1 beta } \\ \text { IL-6 } & \text { Interleukin 6 }\end{array}$




$\begin{array}{ll}\text { JNK } & \text { c-Jun amino-terminal kinases } \\ \text { LDL } & \text { Low-density lipoprotein } \\ \text { MCP-1 } & \text { Monocyte chemoattractant protein-1 } \\ \text { MOI } & \text { Multiplicity of infection } \\ \text { MUFAs } & \text { Monounsaturated fatty acids } \\ \text { NASH } & \text { Nonalcoholic steatohepatitis } \\ \text { NF- } k \text { B } & \text { Nuclear factor-kB } \\ \text { PEA } & \text { Palmitoylethanolamide } \\ \text { Peg-IFN } \alpha & \text { Pegylated interferon alpha } \\ \text { PPARs } & \text { Peroxisome Proliferator-Activated Receptors } \\ \text { pUL37x1 } & \text { UL37x1 protein } \\ \text { ROS } & \text { Reactive oxygen species } \\ \text { SARS-CoV-2 } & \text { Severe acute respiratory syndrome coronavirus 2 } \\ \text { SCD } & \text { Stearoyl-CoA desaturase } \\ \text { SREBP1c } & \text { Sterol regulatory element-binding protein 1c } \\ \text { TCA } & \text { Tricarboxylic acid } \\ \text { TNF- } \alpha & \text { Tumor necrosis factor alpha } \\ \text { VLCFAs } & \text { Very long chain fatty acids } \\ \text { VLDL } & \text { Very-low-density lipoprotein } \\ \text { NSCs } & \text { Neural stem cells }\end{array}$

\section{References}

1. Schelhaas, M. Come in and take your coat off-How host cells provide endocytosis for virus entry. Cell Microbiol. 2010, 12, 1378-1388. [CrossRef]

2. Weissenhorn, W.; Poudevigne, E.; Effantin, G.; Bassereau, P. How to get out: ssRNA enveloped viruses and membrane fission. Curr. Opin. Virol. 2013, 3, 159-167. [CrossRef]

3. Eisenreich, W.; Rudel, T.; Heesemann, J.; Goebel, W. How viral and intracellular bacterial pathogens reprogram the metabolism of host cells to allow their intracellular replication. Front. Cell Infect. Microbiol. 2019, 9, 42. [CrossRef]

4. Valle-Casuso, J.C.; Angin, M.; Volant, S.; Passaes, C.; Monceaux, V.; Mikhailova, A.; Bourdic, K.; Avettand-Fenoel, V.; Boufassa, F.; Sitbon, M.; et al. Cellular metabolism is a major determinant of HIV-1 reservoir seeding in CD4+ T cells and offers an opportunity to tackle infection. Cell Metab. 2019, 29, 611-626.e5. [CrossRef]

5. Kulkarni, M.M.; Ratcliff, A.N.; Bhat, M.; Alwarawrah, Y.; Hughes, P.; Arcos, J.; Loiselle, D.; Torrelles, J.B.; Funderburg, N.T.; Haystead, T.A.; et al. Cellular fatty acid synthase is required for late stages of HIV-1 replication. Retrovirology 2017, 14, 45. [CrossRef] [PubMed]

6. Schwerbrock, N.M.; Karlsson, E.A.; Shi, Q.; Sheridan, P.A.; Beck, M.A. Fish oil-fed mice have impaired resistance to influenza infection. J. Nutr. 2009, 139, 1588-1594. [CrossRef] [PubMed]

7. Sumbria, D.; Berber, E.; Rouse, B.T. Supplementing the diet with sodium propionate suppresses the severity of viral immunoinflammatory lesions. J. Virol. 2021, 95, e02056-20. [CrossRef] [PubMed]

8. Uyangaa, E.; Lee, H.K.; Eo, S.K. Glutamine and leucine provide enhanced protective immunity against mucosal infection with herpes simplex virus type 1. Immune Netw. 2012, 12, 196-206. [CrossRef]

9. Wang, K.; Hoshino, Y.; Dowdell, K.; Bosch-Marce, M.; Myers, T.G.; Sarmiento, M.; Pesnicak, L.; Krause, P.R.; Cohen, J.I. Glutamine supplementation suppresses herpes simplex virus reactivation. J. Clin. Investig. 2017, 127, 2626-2630. [CrossRef] [PubMed]

10. Zhang, D.; Li, J.; Wang, F.; Hu, J.; Wang, S.; Sun, Y. 2-Deoxy-D-glucose targeting of glucose metabolism in cancer cells as a potential therapy. Cancer Lett. 2014, 355, 176-183. [CrossRef] [PubMed]

11. Xi, H.; Kurtoglu, M.; Lampidis, T.J. The wonders of 2-deoxy-D-glucose. IUBMB Life 2014, 66, 110-121. [CrossRef] [PubMed]

12. Pajak, B.; Siwiak, E.; Sołtyka, M.; Priebe, A.; Zieliński, R.; Fokt, I.; Ziemniak, M.; Jaśkiewicz, A.; Borowski, R.; Domoradzki, T.; et al. 2-Deoxy-d-glucose and its analogs: From diagnostic to therapeutic agents. Int. J. Mol. Sci. 2019, 21, 234. [CrossRef]

13. Courtney, R.J.; Steiner, S.M.; Benyesh-Melnick, M. Effects of 2-deoxy-D-glucose on herpes simplex virus replication. Virology 1973, 52, 447-455. [CrossRef]

14. Kilbourne, E.D. Inhibition of influenza virus multiplication with a glucose antimetabolite (2-deoxy-D-glucose). Nature 1959, 183, 271-272. [CrossRef]

15. Radsak, K.D.; Weder, D. Effect of 2-deoxy-D-glucose on cytomegalovirus-induced DNA synthesis in human fibroblasts. J. Gen. Virol. 1981, 57 Pt 1, 33-42. [CrossRef]

16. Gualdoni, G.A.; Mayer, K.A.; Kapsch, A.M.; Kreuzberg, K.; Puck, A.; Kienzl, P.; Oberndorfer, F.; Frühwirth, K.; Winkler, S.; Blaas, D.; et al. Rhinovirus induces an anabolic reprogramming in host cell metabolism essential for viral replication. Proc. Natl. Acad. Sci. USA 2018, 115, E7158-E7165. [CrossRef] [PubMed]

17. Verma, A.; Adhikary, A.; Woloschak, G.; Dwarakanath, B.S.; Papineni, R.V.L. A combinatorial approach of a polypharmacological adjuvant 2-deoxy-D-glucose with low dose radiation therapy to quell the cytokine storm in COVID-19 management. Int. J. Radiat. Biol. 2020, 96, 1323-1328. [CrossRef] [PubMed] 
18. Wakil, S.J.; Abu-Elheiga, L.A. Fatty acid metabolism: Target for metabolic syndrome. J. Lipid Res. 2009, 50 (Suppl. 1), S138-S143. [CrossRef]

19. Currie, E.; Schulze, A.; Zechner, R.; Walther, T.C.; Farese, R.V., Jr. Cellular fatty acid metabolism and cancer. Cell Metab. 2013, 18, 153-161. [CrossRef]

20. Kuhajda, F.P.; Pizer, E.S.; Li, J.N.; Mani, N.S.; Frehywot, G.L.; Townsend, C.A. Synthesis and antitumor activity of an inhibitor of fatty acid synthase. Proc. Natl. Acad. Sci. USA 2000, 97, 3450-3454. [CrossRef]

21. Flavin, R.; Peluso, S.; Nguyen, P.L.; Loda, M. Fatty acid synthase as a potential therapeutic target in cancer. Future Oncol. 2010, 6 , 551-562. [CrossRef]

22. Landree, L.E.; Hanlon, A.L.; Strong, D.W.; Rumbaugh, G.; Miller, I.M.; Thupari, J.N.; Connolly, E.C.; Huganir, R.L.; Richardson, C.; Witters, L.A.; et al. C75, a fatty acid synthase inhibitor, modulates AMP-activated protein kinase to alter neuronal energy metabolism. J. Biol. Chem. 2004, 279, 3817-3827. [CrossRef] [PubMed]

23. Ronnett, G.V.; Kim, E.K.; Landree, L.E.; Tu, Y. Fatty acid metabolism as a target for obesity treatment. Physiol. Behav. 2005, 85, 25-35. [CrossRef]

24. Gaunt, E.R.; Cheung, W.; Richards, J.E.; Lever, A.; Desselberger, U. Inhibition of rotavirus replication by downregulation of fatty acid synthesis. J. Gen. Virol. 2013, 94 Pt 6, 1310-1317. [CrossRef]

25. Ohol, Y.M.; Wang, Z.; Kemble, G.; Duke, G. Direct inhibition of cellular fatty acid synthase impairs replication of respiratory syncytial virus and other respiratory viruses. PLOS ONE 2015, 10, e0144648. [CrossRef]

26. Yang, W.; Hood, B.L.; Chadwick, S.L.; Liu, S.; Watkins, S.C.; Luo, G.; Conrads, T.P.; Wang, T. Fatty acid synthase is up-regulated during hepatitis C virus infection and regulates hepatitis C virus entry and production. Hepatology 2008, 48, 1396-1403. [CrossRef] [PubMed]

27. Li, Y.; Webster-Cyriaque, J.; Tomlinson, C.C.; Yohe, M.; Kenney, S. Fatty acid synthase expression is induced by the Epstein-Barr virus immediate-early protein BRLF1 and is required for lytic viral gene expression. J. Virol. 2004, 78, 4197-4206. [CrossRef] [PubMed]

28. Rassmann, A.; Henke, A.; Jarasch, N.; Lottspeich, F.; Saluz, H.P.; Munder, T. The human fatty acid synthase: A new therapeutic target for coxsackievirus B3-induced diseases? Antivir. Res. 2007, 76, 150-158. [CrossRef]

29. Tracz-Gaszewska, Z.; Dobrzyn, P. Stearoyl-CoA desaturase 1 as a therapeutic target for the treatment of cancer. Cancers 2019, 11, 948. [CrossRef] [PubMed]

30. Igal, R.A. Stearoyl CoA desaturase-1: New insights into a central regulator of cancer metabolism. Biochim. Biophys. Acta 2016, 1861 Pt A, 1865-1880. [CrossRef]

31. Uto, Y. Recent progress in the discovery and development of stearoyl CoA desaturase inhibitors. Chem. Phys. Lipids 2016, 197, 3-12. [CrossRef] [PubMed]

32. Lyn, R.K.; Singaravelu, R.; Kargman, S.; O’Hara, S.; Chan, H.; Oballa, R.; Huang, Z.; Jones, D.M.; Ridsdale, A.; Russell, R.S.; et al. Stearoyl-CoA desaturase inhibition blocks formation of hepatitis $C$ virus-induced specialized membranes. Sci. Rep. 2014, 4, 4549. [CrossRef]

33. Nguyen, L.N.; Lim, Y.S.; Pham, L.V.; Shin, H.Y.; Kim, Y.S.; Hwang, S.B. Stearoyl coenzyme A desaturase 1 is associated with hepatitis $C$ virus replication complex and regulates viral replication. J. Virol. 2014, 88, 12311-12325. [CrossRef] [PubMed]

34. Nio, Y.; Hasegawa, H.; Okamura, H.; Miyayama, Y.; Akahori, Y.; Hijikata, M. Liver-specific mono-unsaturated fatty acid synthase-1 inhibitor for anti-hepatitis C treatment. Antivir. Res. 2016, 132, 262-267. [CrossRef]

35. Hishiki, T.; Kato, F.; Nio, Y.; Watanabe, S.; Wen Tan, N.W.; Yamane, D.; Miyazaki, Y.; Lin, C.C.; Suzuki, R.; Tajima, S.; et al Stearoyl-CoA desaturase-1 is required for flavivirus RNA replication. Antivir. Res. 2019, 165, 42-46. [CrossRef]

36. Wang, Z.; Liu, F.; Fan, N.; Zhou, C.; Li, D.; Macvicar, T.; Dong, Q.; Bruns, C.J.; Zhao, Y. Targeting glutaminolysis: New perspectives to understand cancer development and novel strategies for potential target therapies. Front. Oncol. 2020, 10, 589508. [CrossRef] [PubMed]

37. Gross, M.I.; Demo, S.D.; Dennison, J.B.; Chen, L.; Chernov-Rogan, T.; Goyal, B.; Janes, J.R.; Laidig, G.J.; Lewis, E.R.; Li, J.; et al. Antitumor activity of the glutaminase inhibitor CB-839 in triple-negative breast cancer. Mol. Cancer Ther. 2014, 13, 890-901. [CrossRef] [PubMed]

38. Wicker, C.A.; Hunt, B.G.; Krishnan, S.; Aziz, K.; Parajuli, S.; Palackdharry, S.; Elaban, W.R.; Wise-Draper, T.M.; Mills, G.B.; Waltz, S.E.; et al. Glutaminase inhibition with telaglenastat (CB-839) improves treatment response in combination with ionizing radiation in head and neck squamous cell carcinoma models. Cancer Lett. 2021, 502, 180-188. [CrossRef]

39. Matre, P.; Velez, J.; Jacamo, R.; Qi, Y.; Su, X.; Cai, T.; Chan, S.M.; Lodi, A.; Sweeney, S.R.; Ma, H.; et al. Inhibiting glutaminase in acute myeloid leukemia: Metabolic dependency of selected AML subtypes. Oncotarget 2016, 7, 79722-79735. [CrossRef]

40. Jacque, N.; Ronchetti, A.M.; Larrue, C.; Meunier, G.; Birsen, R.; Willems, L.; Saland, E.; Decroocq, J.; Maciel, T.T.; Lambert, M.; et al. Targeting glutaminolysis has antileukemic activity in acute myeloid leukemia and synergizes with BCL-2 inhibition. Blood 2015, 126, 1346-1356. [CrossRef] [PubMed]

41. Thai, M.; Thaker, S.K.; Feng, J.; Du, Y.; Hu, H.; Ting Wu, T.; Graeber, T.G.; Braas, D.; Christofk, H.R. MYC-induced reprogramming of glutamine catabolism supports optimal virus replication. Nat. Commun. 2015, 6, 8873. [CrossRef]

42. Kim, K.; Kim, K.H.; Kim, H.H.; Cheong, J. Hepatitis B virus X protein induces lipogenic transcription factor SREBP1 and fatty acid synthase through the activation of nuclear receptor LXRalpha. Biochem. J. 2008, 416, 219-230. [CrossRef] 
43. Heaton, N.S.; Perera, R.; Berger, K.L.; Khadka, S.; Lacount, D.J.; Kuhn, R.J.; Randall, G. Dengue virus nonstructural protein 3 redistributes fatty acid synthase to sites of viral replication and increases cellular fatty acid synthesis. Proc. Natl. Acad. Sci. USA 2010, 107, 17345-17350. [CrossRef] [PubMed]

44. Schaefer, E.A.; Chung, R.T. HCV and host lipids: An intimate connection. Semin. Liver Dis. 2013, 33, 358-368. [CrossRef] [PubMed]

45. Sidorkiewicz, M. Hepatitis C virus uses host lipids to its own advantage. Metabolites 2021, 11, 273. [CrossRef]

46. Lavie, M.; Dubuisson, J. Interplay between hepatitis $C$ virus and lipid metabolism during virus entry and assembly. Biochimie 2017, 141, 62-69. [CrossRef] [PubMed]

47. Blaising, J.; Pécheur, E.I. Lipids: A key for hepatitis C virus entry and a potential target for antiviral strategies. Biochimie 2013, 95, 96-102. [CrossRef] [PubMed]

48. Zhang, J.; Ling, N.; Lei, Y.; Peng, M.; Hu, P.; Chen, M. Multifaceted interaction between Hepatitis B virus infection and lipid metabolism in hepatocytes: A potential target of antiviral therapy for chronic Hepatitis B. Front. Microbiol. 2021, 12, 636897. [CrossRef]

49. Wang, C.C.; Tseng, T.C.; Kao, J.H. Hepatitis B virus infection and metabolic syndrome: Fact or fiction? J. Gastroenterol. Hepatol. 2015, 30, 14-20. [CrossRef]

50. Wang, H.; Yang, P.; Liu, K.; Guo, F.; Zhang, Y.; Zhang, G.; Jiang, C. SARS coronavirus entry into host cells through a novel clathrinand caveolae-independent endocytic pathway. Cell Res. 2008, 18, 290-301. [CrossRef] [PubMed]

51. Vastag, L.; Koyuncu, E.; Grady, S.L.; Shenk, T.E.; Rabinowitz, J.D. Divergent effects of human cytomegalovirus and herpes simplex virus-1 on cellular metabolism. PLoS Pathog. 2011, 7, e1002124. [CrossRef]

52. Xi, Y.; Harwood, S.; Wise, L.M.; Purdy, J.G. Human cytomegalovirus pUL37x1 is important for remodeling of host lipid metabolism. J. Virol. 2019, 93, e00843-19. [CrossRef]

53. Pirat, C.; Farce, A.; Lebègue, N.; Renault, N.; Furman, C.; Millet, R.; Yous, S.; Speca, S.; Berthelot, P.; Desreumaux, P.; et al. Targeting peroxisome proliferator-activated receptors (PPARs): Development of modulators. J. Med. Chem. 2012, 55, $4027-4061$. [CrossRef]

54. Cheng, H.S.; Tan, W.R.; Low, Z.S.; Marvalim, C.; Lee, J.Y.H.; Tan, N.S. Exploration and development of PPAR modulators in health and disease: An update of clinical evidence. Int. J. Mol. Sci. 2019, 20, 5055. [CrossRef] [PubMed]

55. Ammazzalorso, A.; Maccallini, C.; Amoia, P.; Amoroso, R. Multitarget PPAR $\gamma$ agonists as innovative modulators of the metabolic syndrome. Eur. J. Med. Chem. 2019, 173, 261-273. [CrossRef] [PubMed]

56. Ammazzalorso, A.; Carrieri, A.; Verginelli, F.; Bruno, I.; Carbonara, G.; D’Angelo, A.; De Filippis, B.; Fantacuzzi, M.; Florio, R.; Fracchiolla, G.; et al. Synthesis, in vitro evaluation, and molecular modeling investigation of benzenesulfonimide peroxisome proliferator-activated receptors $\alpha$ antagonists. Eur. J. Med. Chem. 2016, 114, 191-200. [CrossRef] [PubMed]

57. Benedetti, E.; d’Angelo, M.; Ammazzalorso, A.; Gravina, G.L.; Laezza, C.; Antonosante, A.; Panella, G.; Cinque, B.; Cristiano, L.; Dhez, A.C.; et al. PPAR $\alpha$ antagonist AA452 triggers metabolic reprogramming and increases sensitivity to radiation therapy in human glioblastoma primary cells. J. Cell Physiol. 2017, 232, 1458-1466. [CrossRef] [PubMed]

58. Ammazzalorso, A.; Bruno, I.; Florio, R.; De Lellis, L.; Laghezza, A.; Cerchia, C.; De Filippis, B.; Fantacuzzi, M.; Giampietro, L.; Maccallini, C.; et al. Sulfonimide and amide derivatives as novel PPAR $\alpha$ antagonists: Synthesis, antiproliferative activity, and docking studies. ACS Med. Chem. Lett. 2020, 11, 624-632. [CrossRef]

59. Ammazzalorso, A.; De Lellis, L.; Florio, R.; Bruno, I.; De Filippis, B.; Fantacuzzi, M.; Giampietro, L.; Maccallini, C.; Perconti, S.; Verginelli, F.; et al. Cytotoxic effect of a family of peroxisome proliferator-activated receptor antagonists in colorectal and pancreatic cancer cell lines. Chem. Biol. Drug Des. 2017, 90, 1029-1035. [CrossRef]

60. De Lellis, L.; Cimini, A.; Veschi, S.; Benedetti, E.; Amoroso, R.; Cama, A.; Ammazzalorso, A. The anticancer potential of Peroxisome Proliferator-Activated Receptor antagonists. ChemMedChem 2018, 13, 209-219. [CrossRef]

61. Yan, B.; Chu, H.; Yang, D.; Sze, K.H.; Lai, P.M.; Yuan, S.; Shuai, H.; Wang, Y.; Kao, R.Y.; Chan, J.F.; et al. Characterization of the lipidomic profile of human coronavirus-infected cells: Implications for lipid metabolism remodeling upon coronavirus replication. Viruses 2019, 11, 73. [CrossRef] [PubMed]

62. Yang, J.; Li, H.; Hu, S.; Zhou, Y. ACE2 correlated with immune infiltration serves as a prognostic biomarker in endometrial carcinoma and renal papillary cell carcinoma: Implication for COVID-19. Aging 2020, 12, 6518-6535. [CrossRef]

63. Zhang, Z.; Li, L.; Li, M.; Wang, X. The SARS-CoV-2 host cell receptor ACE2 correlates positively with immunotherapy response and is a potential protective factor for cancer progression. Comput. Struct. Biotechnol. J. 2020, 18, 2438-2444. [CrossRef]

64. Heffernan, K.S.; Ranadive, S.M.; Jae, S.Y. Exercise as medicine for COVID-19: On PPAR with emerging pharmacotherapy. Med. Hypotheses 2020, 143, 110197. [CrossRef]

65. Ehrlich, A.; Uhl, S.; Ioannidis, K.; Hofree, M.; ten Oever, B.; Nahmias, Y. The SARS-CoV-2 Transcriptional Metabolic Signature in Lung Epithelium. SSRN Electron J. 2020. [CrossRef]

66. Rodon, J.; Muñoz-Basagoiti, J.; Perez-Zsolt, D.; Noguera-Julian, M.; Paredes, R.; Mateu, L.; Quiñones, C.; Perez, C.; Erkizia, I.; Blanco, I.; et al. Identification of plitidepsin as potent inhibitor of SARS-CoV-2-induced cytopathic effect after a drug repurposing screen. Front. Pharmacol. 2021, 12, 646676. [CrossRef]

67. Del Re, A.; Corpetti, C.; Pesce, M.; Seguella, L.; Steardo, L.; Palenca, I.; Rurgo, S.; De Conno, B.; Sarnelli, G.; Esposito, G. Ultramicronized Palmitoylethanolamide inhibits NLRP3 inflammasome expression and pro-inflammatory response activated by SARS-CoV-2 Spike protein in cultured murine alveolar macrophages. Metabolites 2021, 11, 592. [CrossRef] 
68. Vallée, A.; Lecarpentier, Y.; Vallée, J.N. Interplay of opposing effects of the WNT/ $\beta$-Catenin pathway and PPAR $\gamma$ and implications for SARS-CoV2 treatment. Front. Immunol. 2021, 12, 666693. [CrossRef]

69. Ciavarella, C.; Motta, I.; Valente, S.; Pasquinelli, G. Pharmacological (or synthetic) and nutritional agonists of PPAR- $\gamma$ as candidates for cytokine storm modulation in COVID-19 disease. Molecules 2020, 25, 2076. [CrossRef] [PubMed]

70. Jagat, J.M.; Kalyan, K.G.; Subir, R. Use of pioglitazone in people with type 2 diabetes mellitus with coronavirus disease 2019 (COVID-19): Boon or bane? Diabetes Metab. Syndr. 2020, 14, 829-831. [CrossRef]

71. Wu, C.; Liu, Y.; Yang, Y.; Zhang, P.; Zhong, W.; Wang, Y.; Wang, Q.; Xu, Y.; Li, M.; Li, X.; et al. Analysis of therapeutic targets for SARS-CoV-2 and discovery of potential drugs by computational methods. Acta Pharm. Sin. B 2020, 10, 766-788. [CrossRef]

72. Carboni, E.; Carta, A.R.; Carboni, E. Can pioglitazone be potentially useful therapeutically in treating patients with COVID-19? Med. Hypotheses 2020, 140, 109776. [CrossRef]

73. Francisqueti-Ferron, F.V.; Garcia, J.L.; Ferron, A.J.T.; Nakandakare-Maia, E.T.; Gregolin, C.S.; Silva, J.P.D.C.; Dos Santos, K.C.; Lo, Â.T.C.; Siqueira, J.S.; de Mattei, L.; et al. Gamma-oryzanol as a potential modulator of oxidative stress and inflammation via PPAR- $\gamma$ in adipose tissue: A hypothetical therapeutic for cytokine storm in COVID-19? Mol. Cell Endocrinol. 2021, $520,111095$. [CrossRef]

74. Talukdar, J.; Bhadra, B.; Dattaroy, T.; Nagle, V.; Dasgupta, S. Potential of natural astaxanthin in alleviating the risk of cytokine storm in COVID-19. Biomed. Pharmacother. 2020, 132, 110886. [CrossRef] [PubMed]

75. AbdelMassih, A.F.; Menshawey, R.; Ismail, J.H.; Husseiny, R.J.; Husseiny, Y.M.; Yacoub, S.; Kamel, A.; Hozaien, R.; Yacoub, E.; Menshawey, E.; et al. PPAR agonists as effective adjuvants for COVID-19 vaccines, by modifying immunogenetics: A review of literature. J. Genet. Eng. Biotechnol. 2021, 19, 82. [CrossRef] [PubMed]

76. Wei, S.; Yang, J.; Lee, S.L.; Kulp, S.K.; Chen, C.S. PPARgamma-independent antitumor effects of thiazolidinediones. Cancer Lett. 2009, 276, 119-124. [CrossRef] [PubMed]

77. Fujita, M.; Yagami, T.; Fujio, M.; Tohji, C.; Takase, K.; Yamamoto, Y.; Sawada, K.; Yamamori, M.; Okamura, N. Cytotoxicity of troglitazone through PPAR $\gamma$-independent pathway and p38 MAPK pathway in renal cell carcinoma. Cancer Lett. 2011, 312, 219-227. [CrossRef]

78. Yamasaki, D.; Kawabe, N.; Nakamura, H.; Tachibana, K.; Ishimoto, K.; Tanaka, T.; Aburatani, H.; Sakai, J.; Hamakubo, T.; Kodama, T.; et al. Fenofibrate suppresses growth of the human hepatocellular carcinoma cell via PPAR $\alpha$-independent mechanisms. Eur. J. Cell Biol. 2011, 90, 657-664. [CrossRef]

79. Davidson, M.A.; Mattison, D.R.; Azoulay, L.; Krewski, D. Thiazolidinedione drugs in the treatment of type 2 diabetes mellitus: Past, present and future. Crit. Rev. Toxicol. 2018, 48, 52-108. [CrossRef]

80. Dharancy, S.; Lemoine, M.; Mathurin, P.; Serfaty, L.; Dubuquoy, L. Peroxisome proliferator-activated receptors in HCV-related infection. PPAR Res. 2009, 2009, 357204. [CrossRef]

81. Dharancy, S.; Malapel, M.; Perlemuter, G.; Roskams, T.; Cheng, Y.; Dubuquoy, L.; Podevin, P.; Conti, F.; Canva, V.; Philippe, D.; et al. Impaired expression of the peroxisome proliferator-activated receptor alpha during hepatitis $\mathrm{C}$ virus infection. Gastroenterology 2005, 128, 334-342. [CrossRef]

82. de Gottardi, A.; Pazienza, V.; Pugnale, P.; Bruttin, F.; Rubbia-Brandt, L.; Juge-Aubry, C.E.; Meier, C.A.; Hadengue, A.; Negro, F. Peroxisome proliferator-activated receptor-alpha and -gamma mRNA levels are reduced in chronic hepatitis $\mathrm{C}$ with steatosis and genotype 3 infection. Aliment. Pharmacol. Ther. 2006, 23, 107-114. [CrossRef]

83. Kim, K.; Kim, K.H.; Ha, E.; Park, J.Y.; Sakamoto, N.; Cheong, J. Hepatitis C virus NS5A protein increases hepatic lipid accumulation via induction of activation and expression of PPARgamma. FEBS Lett. 2009, 583, 2720-2726. [CrossRef]

84. Kurihara, T.; Niimi, A.; Maeda, A.; Shigemoto, M.; Yamashita, K. Study of effectiveness of bezafibrate in the treatment of chronic hepatitis C. Am. J. Gastroenterol. 2001, 96, 1659-1660. [CrossRef]

85. Fujita, N.; Kaito, M.; Tanaka, H.; Horiike, S.; Adachi, Y. Reduction of serum HCV RNA titer by bezafibrate therapy in patients with chronic hepatitis C. Am. J. Gastroenterol. 2004, 99, 2280. [CrossRef] [PubMed]

86. Fujita, N.; Kaito, M.; Kai, M.; Sugimoto, R.; Tanaka, H.; Horiike, S.; Konishi, M.; Iwasa, M.; Watanabe, S.; Adachi, Y. Effects of bezafibrate in patients with chronic hepatitis $C$ virus infection: Combination with interferon and ribavirin. J. Viral Hepat. 2006, 13, 441-448. [CrossRef] [PubMed]

87. Chojkier, M.; Elkhayat, H.; Sabry, D.; Donohue, M.; Buck, M. Pioglitazone decreases hepatitis C viral load in overweight, treatment naïve, genotype 4 infected-patients: A pilot study. PLoS ONE 2012, 7, e31516. [CrossRef]

88. Goldwasser, J.; Cohen, P.Y.; Lin, W.; Kitsberg, D.; Balaguer, P.; Polyak, S.J.; Chung, R.T.; Yarmush, M.L.; Nahmias, Y. Naringenin inhibits the assembly and long-term production of infectious hepatitis $C$ virus particles through a PPAR-mediated mechanism. J. Hepatol. 2011, 55, 963-971. [CrossRef] [PubMed]

89. Young, K.C.; Bai, C.H.; Su, H.C.; Tsai, P.J.; Pu, C.Y.; Liao, C.S.; Lin, Y.M.; Lai, H.W.; Chong, L.W.; Tsai, Y.S.; et al. Fluoxetine a novel anti-hepatitis $C$ virus agent via ROS-, JNK-, and PPAR $\beta / \gamma$-dependent pathways. Antivir. Res. 2014, 110, 158-167. [CrossRef]

90. Lin, Y.M.; Sun, H.Y.; Chiu, W.T.; Su, H.C.; Chien, Y.C.; Chong, L.W.; Chang, H.C.; Bai, C.H.; Young, K.C.; Tsao, C.W. Calcitriol inhibits HCV infection via blockade of activation of PPAR and interference with endoplasmic reticulum-associated degradation. Viruses 2018, 10, 57. [CrossRef]

91. Rakic, B.; Sagan, S.M.; Noestheden, M.; Bélanger, S.; Nan, X.; Evans, C.L.; Xie, X.S.; Pezacki, J.P. Peroxisome proliferator-activated receptor alpha antagonism inhibits hepatitis C virus replication. Chem. Biol. 2006, 13, 23-30. [CrossRef] [PubMed] 
92. Ban, S.; Ueda, Y.; Ohashi, M.; Matsuno, K.; Ikeda, M.; Kato, N.; Miyachi, H. Peroxisome proliferator-activated receptor delta antagonists inhibit hepatitis C virus RNA replication. Bioorg. Med. Chem. Lett. 2013, 23, 4774-4778. [CrossRef]

93. Rauwel, B.; Mariamé, B.; Martin, H.; Nielsen, R.; Allart, S.; Pipy, B.; Mandrup, S.; Devignes, M.D.; Evain-Brion, D.; Fournier, T.; et al. Activation of peroxisome proliferator-activated receptor gamma by human cytomegalovirus for de novo replication impairs migration and invasiveness of cytotrophoblasts from early placentas. J. Virol. 2010, 84, 2946-2954. [CrossRef]

94. Leghmar, K.; Cenac, N.; Rolland, M.; Martin, H.; Rauwel, B.; Bertrand-Michel, J.; Le Faouder, P.; Bénard, M.; Casper, C.; Davrinche, C.; et al. Cytomegalovirus infection triggers the secretion of the PPAR $\gamma$ agonists 15-hydroxyeicosatetraenoic acid (15-HETE) and 13-hydroxyoctadecadienoic acid (13-HODE) in human cytotrophoblasts and placental cultures. PLoS ONE 2015, 10, e0132627. [CrossRef] [PubMed]

95. Rolland, M.; Li, X.; Sellier, Y.; Martin, H.; Perez-Berezo, T.; Rauwel, B.; Benchoua, A.; Bessières, B.; Aziza, J.; Cenac, N.; et al. PPAR $\gamma$ is activated during congenital cytomegalovirus infection and inhibits neuronogenesis from human neural stem cells. PLoS Pathog. 2016, 12, e1005547. [CrossRef] [PubMed] 